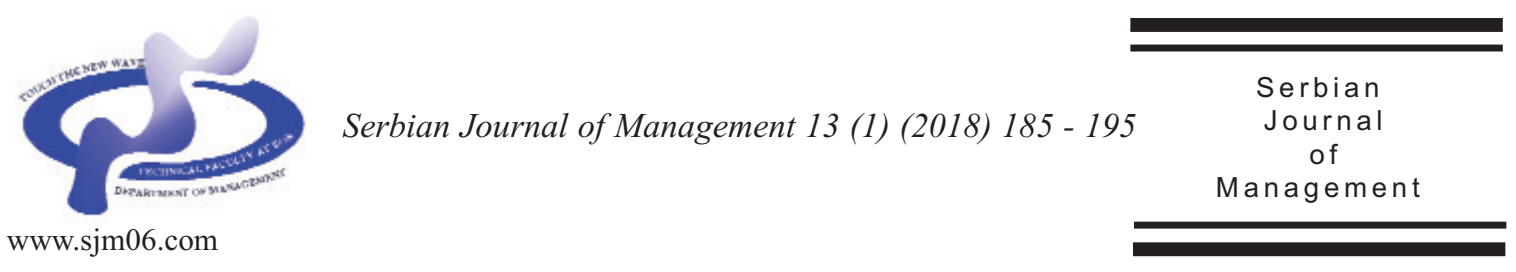

\title{
THE MEDIATING ROLE OF INFLUENCE, VISION AND ENTREPRENEURIAL CONTEXT
}

\author{
Harjit Singha $^{a}$, Ramanjeet Singh ${ }^{\text {** }}$ and Hima Bindu Kotac

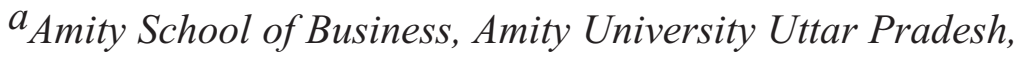 \\ Sector-125, Noida, U.P. (India), 201301, India

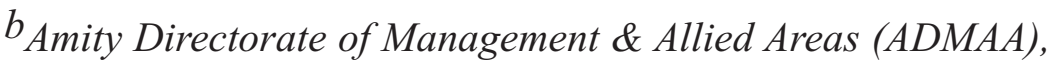 \\ Amity University Uttar Pradesh, Sector-125, Noida, U.P. (India) - 201301, India \\ ${ }^{c}$ Amity Directorate of Management \& Allied Areas (ADMAA), \\ Amity University Uttar Pradesh, Sector-125, Noida, U.P. (India) - 201301, India
}

(Received 3 March 2017; accepted 14 November 2017)

\begin{abstract}
This research work seeks to investigate the issues that inspire an entrepreneur to be successful in his entrepreneurial journey. Mediating role of influence and vision are viewed as inevitable resources for strategic entrepreneurship. The paper sheds lights on the leadership style and analyses the issues related to influence, motivate, restructuring, and contribute to the field's growing body of work. The research study employs a case study method. The interviewees were interviewed by theme questions and secondary information was gathered to strengthen the empirical section. The findings demonstrate that a successful organisation comes in existence not only because of the efforts put in by self-motivated individual who is ready to undertake responsibility of leading and taking risks. This necessitates distinctive quality on the part of an entrepreneur who is always cognizant of the new developments and vagaries surrounding him and does not hesitate to adapt to those changes. The case presents an opportunity for burgeoning entrepreneurs and would-be managers to comprehend how leadership style and entrepreneurial context guarantee entrepreneurial success.
\end{abstract}

Keywords: entrepreneurial success, entrepreneurship, innovation, leadership, management style

\section{INTRODUCTION}

This case study is about Mr. Sriraj, a young management graduate who wanted to make his career in a multinational company but adversities forced him to join his family business. The person who never thought of doing business and was always afraid of simple trading, became an entrepreneur. Several problems came to break the morale

\footnotetext{
* Corresponding author: drramanjeet@gmail.com
}

DOI: $10.5937 /$ sjm13-13334 
of Sriraj but he fought courageously and very soon became millionaire. He did and tried everything that could take his business to new heights and fulfill his father's unaccomplished wishes. He gave up his hobbies, social life to excel in the entrepreneurial journey. From barely two medicines in 2001, his company now owns dozen of successful medicines. From general health care to herbal, herbal to beauty products, beauty products to cosmetics, he earned name and fame. The case begins with decent opening, growth \& success stories, leadership style, problems faced, and tries to seek answers, such as when do employees become entrepreneurs, where do entrepreneurs come from and what approach guarantee entrepreneurial success.

\subsection{Literature Review}

There have been several studies around the globe to highlight the various inherent characteristics of entrepreneurs vis-a-vis reasons for becoming entrepreneur. The prominent among them are self-motivation, passion, and aspiration to lead ahead. The inner motivation and commitment to themselves have evolved as two new major dimensions of their personality. In addition to the outmoded notion that the entrepreneurs are involved in risk taking, that is, they are innovative and creative (Baldoni, 2005).

The acknowledgment and assessment of business opportunities represent the beginning of the entrepreneurial success (Clark \& Oswald 1994). The budding entrepreneurs perceive or build business opportunities that they achieve by small family sized enterprises, generally taking part in the financing of capital for that enterprise or simply selling their innovative ideas (Cacioppe, 1998).

The risk takers within the organizations or managers of large organisations have to reinvent the company each day, by creating new enterprises and taking it to large scale. Normally the people working in the organisations have found to have greater negotiable power and networking with the others (Leith et al., 2012).

The power and effectiveness is increased when they are capable of integrated actions, when they have access or control over the information and when they represent a significant replacing cost for the organization, if they were to leave it (Singh \& Aggarwal, 2013). Kihlstrom (1979) recommended the concept of entrepreneurship as being a possibility to recognize profit opportunities. Furnhum (2002) opined that the activities of first generation entrepreneur are fundamentally competitive. And thus, competition is inherent in the nature of the process on the entrepreneurial marketplace. Or, otherwise said, the entrepreneurial spirit is inherent to the process of competitive market.

According to Katz and Kahn (1978), Murphy (1990) and Kumar et al. (1993) the entrepreneurs are risk takers, who craft, cultivate, and manage a business, risking time, efforts and money to this perseverance. The entrepreneurship as a concept refers to an ability of the individual to put into practice an impression possessing some qualities such as originality, novelty, risk taking, and capability to plan and manage the activities in view of fulfilling the proposed goals.

Churchill (1999) acknowledges that entrepreneurship and successful venture ship recognizes different approaches at the level of each state, being influenced by certain elements such as personal traits, education, 
ethos, and environment, legislative and political system. The decision-making and self-discipline qualities of the entrepreneur have evolved as two new key dimensions of their personality, in addition to the old-style concept that the entrepreneurs are involved in risk taking, that is, they are inventive and imaginative (Hersey et al., 2001).

\subsection{Methodology}

Both primary and secondary data has been used to develop the case study. The protagonist, Siriraj was interviewed and consulted several times to develop the case. Besides this subject experts and existing literature was referred for the clarity of the concept and case building.

\section{THE MAKING OF ENTREPRENEUR}

Successful people encourage other people to become successful. These hopefuls believe that becoming an entrepreneur will allow them to network with people who have already built great empires (Baldoni, 2005). They firmly believe that they have adequate potential to find the next profitable idea and change the lives of millions. Seeing someone with hard to live to become a successful tycoon is enough for these budding entrepreneurs to save up money to start their own businesses (Singh \& Aggarwal, 2012).

The humblest sort of entrepreneurship is self-employment. There is recent survey evidence to suggest that, in the industrialized nations, many individuals who are currently employees would prefer to be self-employed (Clark \& Oswald 1994). Although it cannot be definitive, this evidence suggests that there may be restrictions on the supply of entrepreneurs. There are plenty of reasons why individuals especially working people decide to become entrepreneurs over the more traditional route of becoming employees. They simply decide the life that's right for them, but with the uncertainty of entrepreneurship also comes tremendous freedom and accountability (Cacioppe, 1998).

This research case is about Sriraj, a young management graduate, who had a dream job when he was appointed as a Manager for the Indian Subcontinent for the well-known International Company, Financial Times, UK. He got his initial training in Malaysia. Within a year's time, due to his exceptional performance, he was also given the additional responsibility of being the Country Manager for Higher Education International Tie-ups for the famous publishing house and the parent company, Pearson Education. He had traveled the length and breadth of the country for academic tie-ups between Indian MBA and the Heriot-Watt MBA programs and was crucial in establishing the joint programme in India. After being in the Education industry for many years, he got fascinated with climate change and environmental issues and had an urge to contribute to this area. He joined a reputed NGO working in environmental issues, Development Alternatives.

Although his professional life was going good, he was facing turbulence in his personal life. His father, Mr. K.V.S Rama Sarma, a noted journalist, was battling from throat cancer and his condition was worsening by the day. He was operated upon and his voice box was removed in order to save him. Although, his condition improved for some months, there was a relapse and his condition took the turn for worse. He was not 
going to survive for long.

Mr. Sarma, educated in Germany, was an enterprising person. During his hey days, he started several projects with German counterparts and has always been a visionary. By the time he reached his $60 \mathrm{~s}$, he developed a very strong interest in alternative medicine. He traveled into the hills and researched a lot about alternative ways to improving health. It was during this phase, he developed an herbal formulation for cardiovascular diseases using rare ingredients. This well-researched formulation started showing positive results for a number of people. So, Mr. Sarma started commercial production of the medicine, Arborium Plus. He named his company Redhill Herbals, a name suggested by his Hungarian friend. Although, the medicine was received well and had lot of therapeutic value, Mr. Sarma was not able to expand due to his deteriorating health. Finally, he passed away in December 2008, after battling cancer for three long years.

\section{THE ENTREPRENEURIAL ITCH}

A person, who never wanted to be a businessman, had no option except to handle his father's legacy. Initial three years were very painful and excruciating for the whole family, including Sriraj. Although he had less contribution in the initial stages of formation of Redhill Herbals, he developed an emotional bonding with the company after his father expired. Under no circumstances, he wanted the company to shut down.

Sacrifice is something you need to be willing to make to succeed in business. So he started managing the company alongside his job (Fiedler, 1967). He worked day and night to expand and improve the revenue of the company. Finally, unable to manage commitments from his job as well as the business, he resigned from his job.

Resigning was not an easy decision. He took lot of time to think over his decision. $\mathrm{He}$ was extremely apprehensive. Here was a person, who, during his professional journey was in touch with big names in Indian and UK education industry and very well-known environmental activists, but things changed suddenly for him. He was now, in the line of business, which was new to him and he felt that he was not ready for it.

\subsection{The Journey Begins}

Entrepreneurs don't just want to change their lives; they want to change the world (Furnham, 2002). It took number of months to get the hang of how to improve the business, to fight the negativities that kept raising their heads and made him feel that he took a wrong decision. He kept fighting his daily battles outside to make newer partners and also inside to keep himself positive. Finally, due to sheer determination, grit, perseverance and extremely tough financial planning, he started to contribute to the growth of the company. The consideration of meaning and doing work that changes the world is something that drives every entrepreneur. The company now has distribution in different parts of the country and also to countries like Sri Lanka. The sales started to increase steadily and above the general market average.

\subsection{About Redhill Herbal Private Limited (RHPL)}

Redhill Herbal Private Limited was established by Sri K.V.S. Rama Sarma in the year 2004 and taken over by Sriraj in late 
2008 is not only a company but an effort - an effort to provide healthy lives to common man. It is all about improving health so that who so ever has come in this world should live a healthy life. Though in modern times work pressure, sedentary life style, and the race to move ahead, cannot be overcome but a way can be find out where effort is not to suppress the signs and symptoms alone but to end the root cause of a disease.

The herbs are picked up right from the Himalayan belt and farms thereby utilizing the natural herbs vis-à-vis increasing the effective income of the farmers. The herbal based products then are made available to a common people especially in the urban areas that is reeling under the scourge of polluted food items and artificial food that make them vulnerable to a variety of chronic diseases. And all this at a cost that is unbeatable in the present market. As most of the available medicines believe in suppressing the signs and symptoms and never appreciate to remove the disease causing factors from the body. Redhill herbals tried to understand the root cause first and then applies the same understanding to root out the disease from the body, this is the reason that made the company different from its peers.

\subsection{The Vision and Philosophy}

Successful entrepreneurship is all about dreaming and imagination and perhaps even a dash of insanity (Hennessey, 1998). Entrepreneurs are the ones who spend most of their productive time in imagination and thinking for innovation (Howell \& Avolio, 1993). They see the world as they want it to be, not how it is. From the genius idea that drove the Wright Brothers to craft a flying machine to the insanity that drove Steve Jobs and Bill Gates to develop new generation computers, entrepreneurs pursue the ideas that others deem crazy (Singh \& Aggarwal, 2013).

The primary vision to set up RHPL was to produce natural, side effect free medicine for today's life-style diseases like depression, heart and cardiovascular problems in a cost effective manner so that they are within the reach of common man. Company believes the detoxification as a primary part of the treatments and considers that until unless the disease causing factors are available in the body, diseases will keep on popping up again and again.

A sincere logic will get an entrepreneur from A to B but a logical Imagination will take you everywhere. The company believes in healthy people for a strong nation. Not opting for the route of manufacturing general analgesics. RHPL took itself the challenge to confront vexing health problems of new generation such as heart attacks and AIDS. A prolonged and detailed \& NBSP research has gone into the making of most of its medicines. The medicines are manufactured from rare herbs procured from Himalayas, which is undoubtedly the greatest repository of nature's gift to the mankind. The company believes that if the nature permitted frightening diseases to exist and spread, it also provided the solutions hidden in its extraordinary flora. Discovering them is painstaking and at times frustrating but at RHPL, entire R\&D team is committed with continuous improvement in quality and effectiveness.

\subsection{The Innovations}

He brought lot of new things in the company:

1. Clinical Trials: Entrepreneurs are never satiated with the knowledge they have 
-they are always seeking more (Eckhardt \& Shane, 2003). Clinical trials are actually unheard of in the ayurvedic industry. Redhill Herbals has two clinical trials on the effect of Arborium Plus on Cholesterol and Varicose Veins by R. A. Poddar Ayurvedic College and SRM University respectively.

2. Lean and mean organization: If you find that learning interests you, from formal education to on-the-job discoveries, and that you can never know enough about the things that excite you, then you have identified one of the genuine reasons individuals are driven to be entrepreneurs. Sriraj doesn't believe in increasing overheads. That is the main reason of him surviving and improving the growth of company. A number of employees are on fixed salary plus commission basis, where their compensation increases with the increase in sales.

3. Regular contact with people: Most of the people struggle with respecting authority. They don't like the realism of having people in superior positions managing their work and looking over their shoulder. Sriraj goes one step further and believes that people are the most important assets of any organization. $\mathrm{He}$ is in touch with his frontline sales officers every day. $\mathrm{He}$ is a great motivator and sees value in people. Through his dedication and focus, he has been able to retain, motivate and engage his sales personnel to bring out their best.

4. Regular meeting with the prescribing Doctors and Distributors: The reality of working an average job doesn't seem rewarding to aspiring entrepreneurs. Having to finish unfulfilling tasks seems really boring to them. Sriraj believes in regularly going and meeting all the doctors that prescribe the medicines manufactured by his firm. He has developed a personal relationship and a tremendous recall value by meeting his distributors as well. This is the reason he travels most of the time in any month.

5. Custom made packaging for Doctors: Keeping existing customers is critical to the long-term success of any business. They can be the source of repeat business, additional business and referrals of quality prospects. Being a nimble organization, Redhill Herbals under the leadership of Sriraj is high on innovative quotient. He has introduced custom made packaging for Doctors with the name and address of their clinics in the outer carton box. This becomes a unique collaboration between the Doctors and Redhill Herbals.

\subsection{Driving Culture Change at RHPL: The Sriraj Way}

Making of a successful entrepreneur takes inspiration, innovation, commitment, leadership, focus and, above all, persistence for what you're trying to do (Finkle et al., 2006). In 2009, when Sriraj was appointed as Chairman of RHPL, General Manager was in the process of restructuring the marketing and HR teams vis a vis business expansion in and outside the country. Sriraj's management style focused on delegating power to managers so as to make RHPL a lean organization. He realized that RHPL was caught in a bureaucratic tradition. As per practice, employees especially the marketing staff were supposed to develop a dress code covering the needs of a variety of workers including R\&D staff and managers as well as salespeople. The general dress code prepared by the RHPL included specific instructions like, "RHPL employees can't wear T-shirts, abnormal jeans that have words on them that could be misinterpreted". Sriraj changed the 
dress code manual and made it just, "Dress appropriately."

\section{LEADERSHIP AND MANAGEMENT STYLE}

Doing a successful business that focuses on social good is no different than starting any other business (Deluga 1992). You need to inculcate the following vital elements in your leadership and management style namely (a). A clear understanding of a need (b). A well-formed plan for how you will reach people with that need and (3). An idea for a product or service to meet the need. Peers opined that Sriraj exemplified all the traits of a comprehensive leader. $\mathrm{He}$ emphasized expansion and collaboration. Sriraj was known for his interpersonal skills and focus on the customer. He relied on team-building and held 'frequent meetings' to seek advice on marketing and sales effort and consumer feedback. Describing Sriraj's leadership style, Mr. Ahmad, RHPL's marketing manager, who has worked with him in different capacities for ten years, said, "Sriraj is trying to bring system to the business. He is energetic, flexible and painstaking. By nature, he is proactive, soft spoken and an outstanding listener which makes him competent to chase big goals and managing diverse teams.

\subsection{The Makeover}

Entrepreneurs are crazy people. They create employment, they make people rich, they pay taxes to the government, they invent things, they contribute to the nation's GDP and list goes on (Fiet, 2001). In March 2011, Sriraj made it mandatory for all of its existing employees to go for training to enhance their existing skills and make them ready for future challenges. But contrary to expectations, Sriraj faced huge criticism as most of its employees were not ready to attend training program. Further, his decision to introduce 'performance appraisal' system for growth and promotion was denied by one and all. Employees warned him to go on strike as they conceived it as an instrument of punishing non-performers. All of his written and verbal commitments to ensure that these changes are for their overall benefit and management has no desire to identify non-performers, went in vain. Sriraj was dancing between the horns of dilemma whether to withdraw changes or implement them forcefully. When all the efforts went waste, he very tactfully started taking prominent managers and key employees in his confidence and through 'one to one' round, was ultimately able to convince them that the planned policy changes are in favour of everyone. For getting best of one's work performance, the gap between ability and willingness has to be filled which helps in improving the level of performance of subordinates. It worked well. Convinced managers were also able to persuade their staff and colleague not to oppose management's new initiatives for the time being. After few months, all felt contented and now on date, have been enjoying in their positions.

\subsection{Expanding the Market}

Expansion and passion is what gets entrepreneurs started and keeps them there. It gives entrepreneurs the ability to convince others to believe in their vision (Stogdill, 1998; van Knippenberg et al., 2005). Though it can't be substitute for planning, but it will help them to stay focused and to get others to 
look at their plans (House, 1977). Sriraj adopted very hands down approach of expanding market. He believed in actually going to all his distributors across the country, meeting them regularly and trying to increase the pockets of generating sales.

He collaborated with his distributors to appoint young, energetic sales personnel along the length and breadth of the country for expanding the market. He conducted regular sales sessions and equiped his sales tem with enough marketing materials to tap the market. His efforts worked well and therefore, he successfully forayed into exports and have got approval in countries like Malaysia, Bangladesh and Sri Lanka.

\subsection{Tackling Challenges}

Successful entrepreneurs enjoy taking challenges and like to win. Constant struggle with competition to win business and grow market share is their strength. To go the extreme, taking issues and challenges personally and use all of this to focus inward and grow a business from nothing into a powerhouse is what sparks them.

Sriraj's never give up attitude helps in tackle most of his challenges and emerge as a winner in most of the situations. He believes that "An entrepreneur's patience must begin where everyone else's fail". During the course of his entrepreneurial journey, he faced several challenges and faced them with sheer grit and determination and has emerged a winner.

One of the biggest challenges Sriraj faced was when he was introduced in the company by his father. Some of the "so called" trusted partners of the company did not like his coming on board. They stood up against him, broke away from the company and also started another product with a similar sounding name. This was a huge blow for RHPL and Sriraj.

However, Sriraj took the challenge face on and worked day and night to build partnerships through the country and today is much ahead of his competition.

Acute entrepreneurs never get to success alone. They believe in team building and understand the power of network of contacts, business partners, financial partners, peers and resources to succeed. Such aspiring entrepreneurs nurture these relationships and surround themselves with people who can help make them more effective. Any good leader is only as good as those who support him. Similarly, there were several challenges that Sriraj faced and emerged victorious due to grit and determination and innovative thinking capabilities.

\subsection{Early Successes and Challenges}

Though initially RHPL showed average returns but after 2012, company showed spectacular performances. Its finances grew several folds. Employees were also promoted and given increment. By mid2016, RHPL had expanded into forty Indian Cities with commission based outlets. The company, which started with just three employees, had increased its manpower to 54 by 2016.

Successful entrepreneurs are never afraid of failure. Though they don't want to commit any mistake but in case, it happens, they learn from their own mistakes and convert their failures or complaints in to compliments. They are generally successful despite of all odds because they are calculating and able to make the best decisions in even the worst of cases. Analyst opined that Sriraj's tenure as CEO has been embarked by both disappointment and 
opportunities. ; the opportunity came in terms of expanding markets and more and more people using Arborium Plus and benefitting from it, thereby winning customer confidence.

The slow sales trend in the market was a big disappointment for Sriraj early on. However, with his hand on approach and his innovative and out-of-the box thinking abilities and never-say-die attitude, Sriraj successfully cleared his early hurdles.

Entrepreneurs believe that in spite of their best effort possible, outcome may not always achieve as per expectations. He firmly believed in olden times' philosophy that "nothing ventured, nothing gained," that's exactly what he still says "do not be afraid to fail, put it out there and give it your best shot". Philosophy worked well, in 2016, RHPL sold more than two hundred thousand bottles of Arborium Plus worldwide despite facing competition from other Ayurveda suppliers.

\subsection{The Way Ahead}

Successful entrepreneurs normally depict robust personalities overall. They are always ready to learn and seldom afraid to ask questions when it means the answers will provide them understanding they can then leverage to effect. Successful entrepreneurs are confident, but not self-centered to the point that their bull-headedness is a weakness that continually prohibits them from seeing a bigger picture and ultimately making the best decisions for the business.

Sriraj's future challenge would lie in achieving higher scale of his operations. His aim is to develop newer formulations to help people tackle with life style diseases in a natural way and export to atleast 20 countries worldwide.

\section{$5 . \quad$ CONCLUSION RECOMMENDATION}

AND

(i). Considering the essence of leadership is influence, vision and entrepreneurial context, successful entrepreneurship could broadly be considered as an art of motivating others to want to struggle for shared vision. However, it could be argued that 'influence and motivation' are essential for entrepreneurial success but efforts put in by self-motivated individual who is ready to assume responsibility of leading and taking risks, makes the real difference. At the same time, the literature also suggests that empirical evidence on the link between entrepreneurial outcome and performance in an organizational context is limited and inadequate. Consequently the study undertaken investigated the effect of different leadership styles on organizational performance.

(ii). The findings also require distinctive quality on the part of an individual better say entrepreneur who is always conscious of the new developments and changes taking place around him in the society and is ready to adapt to the changing needs of the society.

(iii). Previous findings of the similar studies assert that entrepreneurial context and the dynamic capabilities on the part of the entrepreneur are necessary for the growth and competitiveness of successful entrepreneurship (Baldoni, 2005; van Knippenberg et al., 2005; Singh \& Aggarwal, 2012). The study goes one step ahead and also appreciates the significance of 'succession-planning' in family businesses to prevent any uncertainty of an enterprise. Besides this, learning about the innovative business practices adopted by Redhill and the steps taken that equipped the company to renovate whenever required are appreciative. 


\title{
ПОСРЕДНА УЛОГА УТИЦАЈА, ВИЗИЈЕ И ПРЕДУЗЕТНИЧКОГ КОНТЕКСТА
}

\author{
Harjit Singh, Ramanjeet Singh, Hima Bindu Kota
}

\section{Извод}

Овај рад настоји да истражи питања која инспиришу предузетника да буде успешан у свом предузетничком подухвату. Посредна улога утицаја и визије сматра се неизбежним ресурсима за стратегијско предузетништво. У раду се указује на стил лидерства и анализирају питања која се односе на утицај, мотивацију, реструктурирање и даје допринос овом растућем пољу истраживања. У истраживању се користи метод студије случаја. Испитаници су интервјуисани тематским питањима, и прикупљене су секундарне информације како би се ојачао емпиријски део. Резултати показују да успешна организације не настаје само због напора које је уложила самомотивицана особа која је спремна да преузме одговорност за вођење и преузимање ризика. То захтева изузетан квалитет предузетника који је увек упознат са новим развојем и кретањима у окружењу и не оклева да се прилагоди овим променама. Студеија случаја представља шансу новим предузетницима и потенцијалним менаџерима да схвате како стил лидерства и предузетнички контекст гарантују предузетнички успех.

Кључне речи: предузетнички успех, предузетништво, иновација, лидерство, стил руковођења

\section{References}

Baldoni, J. (2005). Motivation Secrets: Great Motivation Secrets of Great Leaders. Online Edition, Available on http://govleaders.org/motivation_secrets.htm

Cacioppe, R. (1998). An integrated model and approach for the design of effective leadership development programs. Leadership and Organization Development Journal, 19 (1), 44-53.

Churchill, G.A. (1999). Marketing Research: Methodological foundations. Seventh Edition. Fort Worth: Dryden Press, USA.

Clark, A.E., \& Oswald, A.J. (1994).
Unhappiness and unemployment. Economic Journal, 104, 648-659.

Deluga, R.J. (1992). The relationship of leader-member exchange with laissez faire, transactional, transformational leadership in naval environments, in Clark, K.E., Clark, M.B. and Campbell, D.P. (Eds), Impact of Leadership, Centre of Creative Leadership, Greensboro, NC, pp. 242-45.

Eckhardt, J.T., \& Shane, S.A. (2003). Opportunities and entrepreneurship. Journal of Management, 29, 333-349.

Fiet, J.O. (2001). The pedagogical side of entrepreneurship theory. Journal of Business Venturing, 16, 101-117.

Fiedler, F.E. (1967). A Theory of 
Leadership Effectiveness. New York: McGraw-Hill.

Finkle, T.A., Kuratko, D.F., \& Goldsby, M.G. (2006). An examination of entrepreneurship centers in the United States: A national survey. Journal of Small Business Management, 44, 184-206.

Furnham, A. (2002). Managers as change agents. Journal of Change Management, 3 (1), 24-27.

Hennessey, J.T. (1998). Reinventing Government: Does Leadership Make the Difference? Public Administration Review, 58 (6), 522-532.

Hersey, P., Blanchard, K., \& Johnson, D.E. (2001). Management of Organizational Behavior, 8th ed., Prentice Hall, Englewood Cliffs, NJ, USA.

House, R.J. (1977). A 1976 theory of charismatic leadership. In: J.G. Hunt \& L.L. Larsons (eds.) Leadership: The Cutting Edge. Carbondale, IL: Southern Illinois University Press, 189-207.

Howell, J.M., \& Avolio, B.J. (1993). Transformational leadership, transactional leadership, locus of control, and support for innovations: key predictors of consolidatedbusiness-unit performance. Journal of Applied Psychology, 78 (6), 891- 903.

Katz, D., \& Kahn, R.L. (1978). The Social Psychology of Organizations, 2nd ed., John Wiley and Sons, New York, NY.

Kihlstrom, R. E., \& Laffont, J. J. (1979). A General Equilibrium Entrepreneurial Theory of Firm Formation Based on Risk Aversion. Journal of Political Economy 87 (4), 719-748.

Kumar, N., Stern, L.W., \& Anderson, J.C. (1993). Conducting inter-organizational research using key informants. Academy of Management Journal, 36 (6), 1633-1651.

Leitch, C.M., McMullan, C., \& Harrison, R.T. (2013). The Development of
Entrepreneurial Leadership: The Role of Human, Social and Institutional Capital. British Journal of Management, 24, 347-366.

Murphy, P.R., Dalenberg, D.R., \& Daley, J.M. (1990). Improving Survey Responses with Postcards. Industrial Marketing Management, 19, 352-354.

Singh, H., \& Aggarwal, N. (2012). Tupperware: achieving sustainable development goals through elevating socioeconomic status of women in India. International Journal of Business Performance Management, 13 (1), 18-27.

Singh, H. \& Aggarwal, N. (2013). Achieving sustainable development goals through elevating socio-economic status, Competitiveness Review. An International Business Journal, 23 (4/5), 398-407.

Stogdill, R.M. (1998). Personal Factors Associated with Leadership. Journal of Psychology, 25, 35-71.

Van Knippenberg, B., van Knippenberg, D., De Cremer, D., \& Hogg, M.A. (2005). Research in leadership, self, and identify: A sample of the present and a glimpse of the future. The Leadership Quarterly, 16, 495499. 